\title{
Salary Negotiations and Gender in Engineering Education
}

\section{Grace Panther, Oregon State University}

Grace Panther is a doctoral student conducting research in engineering education. She has experience conducting workshops at engineering education conferences and is currently a guest editor for a special issue of European Journal of Engineering Education on inclusive learning environments. Her research includes material development, faculty discourses on gender, and defining knowledge domains of students and engineers.

\section{Dr. Kacey Beddoes, University of Massachusetts, Lowell}

Kacey Beddoes received her Ph.D. in Science and Technology Studies (STS) from Virginia Tech, along with graduate certificates in Women's and Gender Studies and Engineering Education. Dr. Beddoes serves as Deputy Editor of the journal Engineering Studies. Further information can be found on her website: www.sociologyofengineering.org

\section{Dr. Cheryl Llewellyn, University of Massachusetts Lowell}




\section{Salary Negotiations and Gender in Engineering Education}

\section{Introduction}

A gendered wage gap persists in academia whereby men are consistently paid more than women, even when factors such as discipline and productivity are controlled for [1]. For instance, in one study, women were found to earn $21 \%$ less than their male peers. Even after controlling for several individual and disciplinary differences, women still earned less than men by $6.8 \%$ [2]. This disparity of women earning less than men was even found at unionized institutions, although the salary gap is narrowed somewhat [3]. As one example, two of the authors' home institution is unionized, yet men assistant professors' average salary was \$2591 higher than women assistant professors, and men full professors' average salary was $\$ 4604$ higher than women full professors in 2014 [4].

One popular explanation for the wage gap has been that women are less likely than men to negotiate their salaries [5]. Negotiating one's salary is critical not only for starting salary, but also for lifetime earnings, as future raises and promotions are based on initial salary. Moreover, in addition to salary, faculty members must decide if and how to negotiate for a wide range of items, including start-up funds, lab space and equipment, relocation expenses, and course reduction. While we know the wage gap exists, and that women faculty members often have less lab space (as one example), we know very little about how negotiation processes actually play out and what factors affect the outcomes. In order to begin to explore those processes and factors, this paper addresses the following research questions:

1. Are women faculty members less likely to negotiate than men?

2. Do gender differences exist in the outcomes of negotiations?

3. Can any disciplinary or institutional factors be identified that have an effect on negotiations?

\section{Prior Literature and Hypotheses}

Research Question 1: Are women faculty members less likely to negotiate than men?

One common explanation for a difference in pay between men and women is that women simply do not attempt to negotiate [6], [7]. One study found that among a group of students graduating from a master's program, men were eight times more likely to negotiate their starting salary compared to women (57\% vs. 7\%) [7]. This finding has been echoed by others as well [8], [9]. Many of the traits that are culturally conditioned into women from a young age make negotiating difficult for women compared to men [10]. Examples of such contributing factors include social psychological factors that make self-advocacy costly for women, women undervaluing themselves, and feeling uncomfortable or not entitled to negotiate [7], [10]. In one study, men felt entitled to more compensation, whereas women felt they were entitled to the same compensation as others. Men also reported more often that they felt like they had to prove themselves during the negotiation process, while women reported more often that they had to prove themselves in the job [11]. 
Therefore, we hypothesized that:

- Hypothesis 1a. Compared to men, women will, on average, be less likely to negotiate their salary.

- Hypothesis $1 b$. In engineering, women will, on average, be less likely to negotiate their salary compared to men.

- Hypothesis 1c. Compared to men, women will, on average, be more likely to be told not to negotiate.

- Hypothesis $1 \mathrm{~d}$. Compared to men, women will, on average, be less likely to receive advice about negotiating.

Research Question 2: Do gender differences exist in the outcomes of negotiations?

When negotiating does occur, women approach the negotiating table differently compared to men. First, men initially ask for a higher salary when negotiating and are more assured in their worth compared to women [11]. Women are more likely to face resistance when negotiating because it is seen as a violation of gender norms and goes against the stereotype that women are less demanding and self-interested [5], [12], [13]. Second, the genders of the people involved in negotiations can also impact the outcome of the negotiation [8], [12], [14]. Women have reported feeling more nervous when attempting to negotiate with men, which impacted how often women initiated negotiations. In contrast, men were twice as likely as women to initiate a negotiation when the person they were negotiating with was a woman [8]. In another study, women who initiated negotiations were penalized more than men [12]. Therefore, we hypothesized that:

- Hypothesis 2a. Compared to women who negotiate, men who negotiate will receive a greater percent increase over their initial offer.

- Hypothesis $2 \mathrm{~b}$. Compared to women who negotiate with men, women who negotiate with women will, on average, have a greater percent increase in salary.

Research Question 3: Can any disciplinary or institutional factors be identified that have an effect on negotiations?

To the best of our knowledge, questions about the ways in which institutional and disciplinary factors affect negotiations have not been addressed in prior studies. Therefore, several exploratory hypotheses, not necessarily grounded in prior literature, were also tested. We hypothesized that:

- Hypothesis 3a. The discipline someone works in influences the percent increase in salary negotiation.

- Hypothesis $3 \mathrm{~b}$. Those who negotiate at PhD-granting universities will have a greater percent increase during salary negotiations.

- Hypothesis 3c. Those who negotiate at unionized universities will have a greater percent increase during salary negotiations.

- Hypothesis $3 \mathrm{~d}$. Those who negotiate at larger universities will have a greater percent increase during salary negotiations.

\section{Methods}

The survey was an online questionnaire designed specifically for tenured and tenure-track professors in departments of engineering, biology, psychology, sociology, and philosophy. It was anticipated that the study would take respondents approximately 15 minutes to complete. 
Responses were anonymous and no identifying information was collected. Respondents had the option to enter their contact information after completing the survey to be entered into a raffle to win a $\$ 300$ Amazon gift card. It was communicated that contact information would not be attached to survey responses in any way.

\section{Survey Design}

The survey was designed to collect demographic information $(\sim 25 \%)$, quantitative data $(\sim 50 \%)$, and qualitative data $(\sim 25 \%)$. Respondents were allowed to skip any questions that they did not want to answer. The quantitative portion focused on the respondents' experience negotiating their most recent salary. For example, one question asked about the initial compensation offered to the respondent before negotiations occurred, including salary and additional compensation (e.g. start up funds, graduate student funding). The goal of collecting quantitative data was to see how negotiations varied among respondents. The qualitative portion pertained to negotiation advice and if the respondent would do anything differently in the future when negotiating compensation. Respondents were asked to share what advice they would give to women and men on the academic job market. The goal of the qualitative data was to see how respondents viewed negotiation based on gender and if there were any differences in the types of advice people give based on gender of the receiver. This paper presents results from the quantitative portion only, and the qualitative portion will be analyzed in a future article.

\section{Data Collection and Analysis}

Distribution of the survey was done by email through the research team's professional networks and listservs, including the Education Research Methods Division of the American Society for Engineering Education, American Society of Civil Engineers department head listserv, the national NSF ADVANCE program listserv, and the engineering education PEER Collaborative listserv. Flyers were also given out and posted at conferences including American Sociological Association national conference and a philosophy conference at University of Massachusetts Lowell. Additionally, the survey was advertised on the website of the lead researcher's research group and ResearchGate.com page, and a representative from ASA tweeted about it from his personal Twitter account. The survey was online for approximately 1 year and in total received over 300 responses, the majority of which were from engineering faculty members. Not all surveys were complete.

Chi-Square analyses were conducted using IBM SPSS. Complete survey responses for research question 1 ranged from 170 to 258, with $\mathrm{n}$ for each hypothesis reported below. The number of complete survey responses for research questions 2 and 3 was 73 . For research questions 2 and 3 , a new variable, "percent increase", was created with the following equation: $\left(\frac{\text { Negotiated Salary-Initial Salary }}{\text { Initial Salary }}\right) \times 100$. Calculating a percent increase allowed for comparisons across disciplines and rank which was necessary due to only 73 of the original $300+$ respondents answering both the negotiated salary question and the initial salary question. Of those 73, 29 were men and 44 were women with a total of 37 responses from engineering faculty members. Dividing the 73 complete responses into finer grain groups beyond what is presented in the results section would have resulted in small cell counts and significance would be difficult to determine. 


\section{Results}

Research Question 1: Are women faculty members less likely to negotiate than men?

Across all disciplines, women reported negotiating their salary more frequently compared to men $(60 \%$ vs. $48 \%)$. This difference was not statistically significant $\left(n=258, \chi^{2}=3.45, p=.063\right)$ and had an effect size of small or minimal $(\Phi=.12)[15]$, [16]. Therefore, hypothesis 1a was rejected as no statistical difference was found between men and women negotiating their salaries.

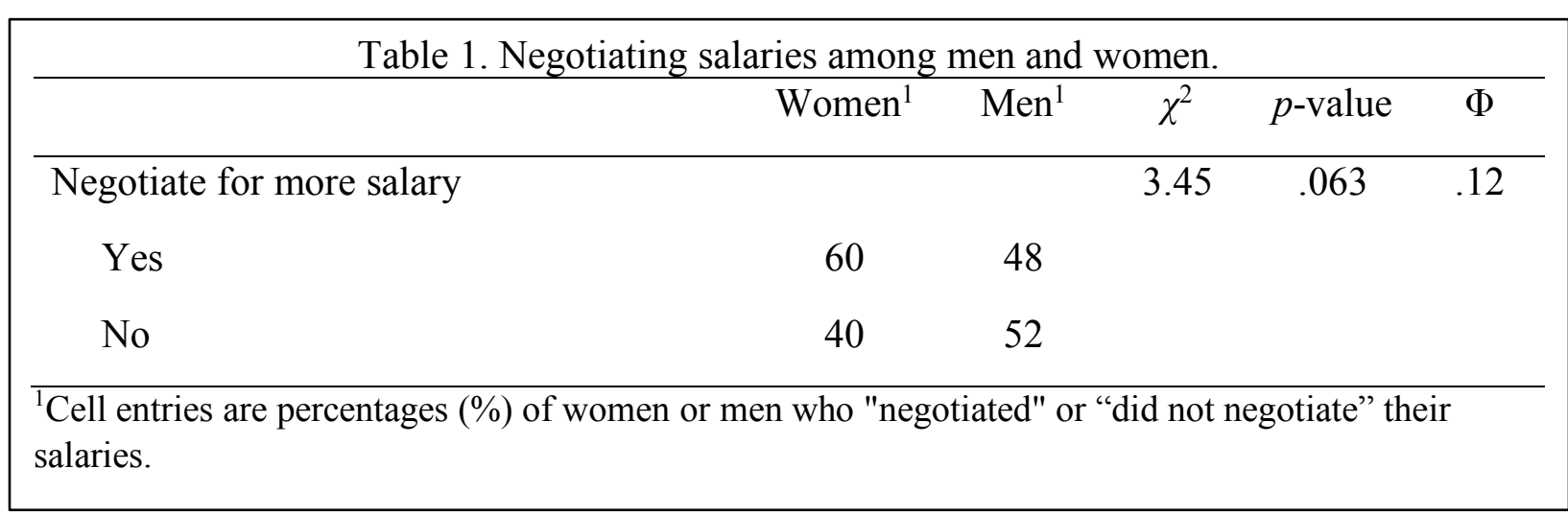

In engineering specifically, women and men equally reported negotiating their salaries (both $46 \%)$. No statistical difference was found $\left(n=170, \chi^{2}=.00, p=.997\right)$. Therefore, hypothesis $1 \mathrm{~b}$ was rejected as no difference was found between men and women in engineering who negotiated their salaries.

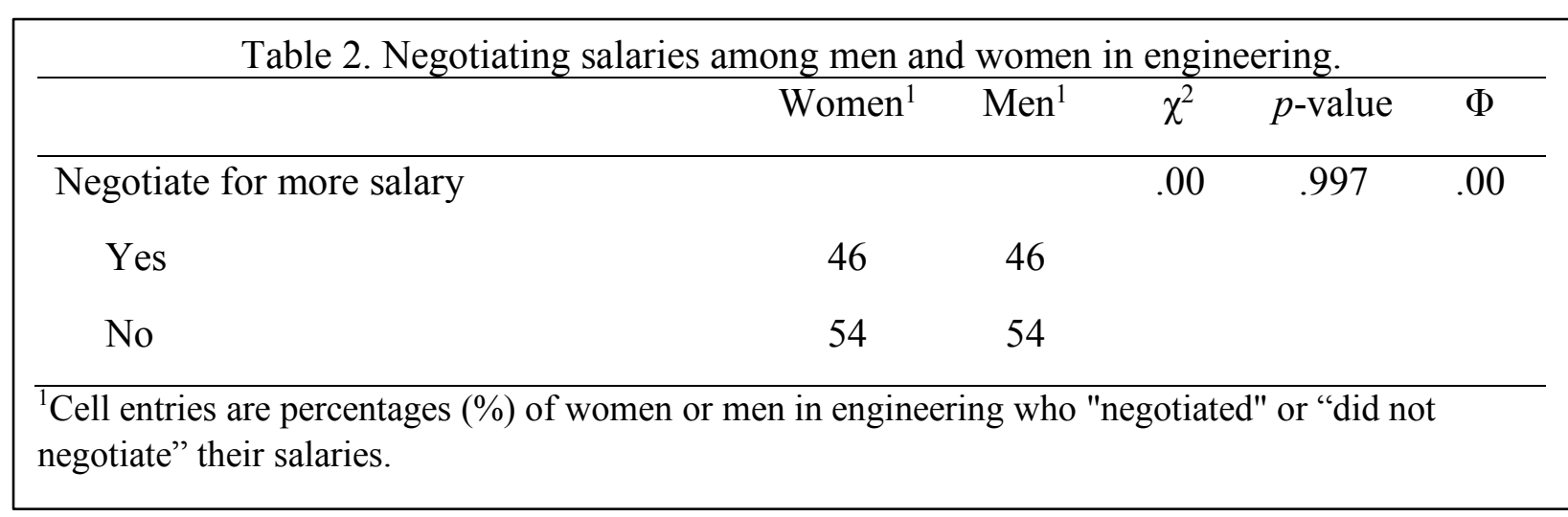

Women reported more frequently that they were told not to negotiate their salaries compared to men $(19 \%$ vs. $15 \%)$. This difference was not statistically different $\left(n=255, \chi^{2}=.727, p=.394\right)$. Therefore, hypothesis $1 \mathrm{c}$ was rejected as no difference was found between men and women being told not to negotiate. 


\begin{tabular}{|c|c|c|c|c|c|}
\hline & Women $^{1}$ & Men $^{1}$ & $\chi^{2}$ & $p$-value & $\Phi$ \\
\hline Told not to negotiate salary & & & .727 & .394 & .05 \\
\hline Yes & 19 & 15 & & & \\
\hline No & 81 & 85 & & & \\
\hline \multicolumn{6}{|c|}{$\begin{array}{l}{ }^{1} \text { Cell entries are percentages }(\%) \text { of women or men who were "told not to negotiate salary" or weren't } \\
\text { "told not to negotiate" their salaries. }\end{array}$} \\
\hline
\end{tabular}

Women more frequently reported receiving advice about negotiating for more salary (45\%) compared to men $(23 \%)$. This difference was statistically significant $\left(n=254, \chi^{2}=14.91, p<\right.$ $.001)$. The effect size was between small or minimal and medium or typical $(\Phi=.24)[15],[16]$. Therefore, hypothesis 1d was rejected as women were more likely to receive advice about negotiating their salaries compared to men.

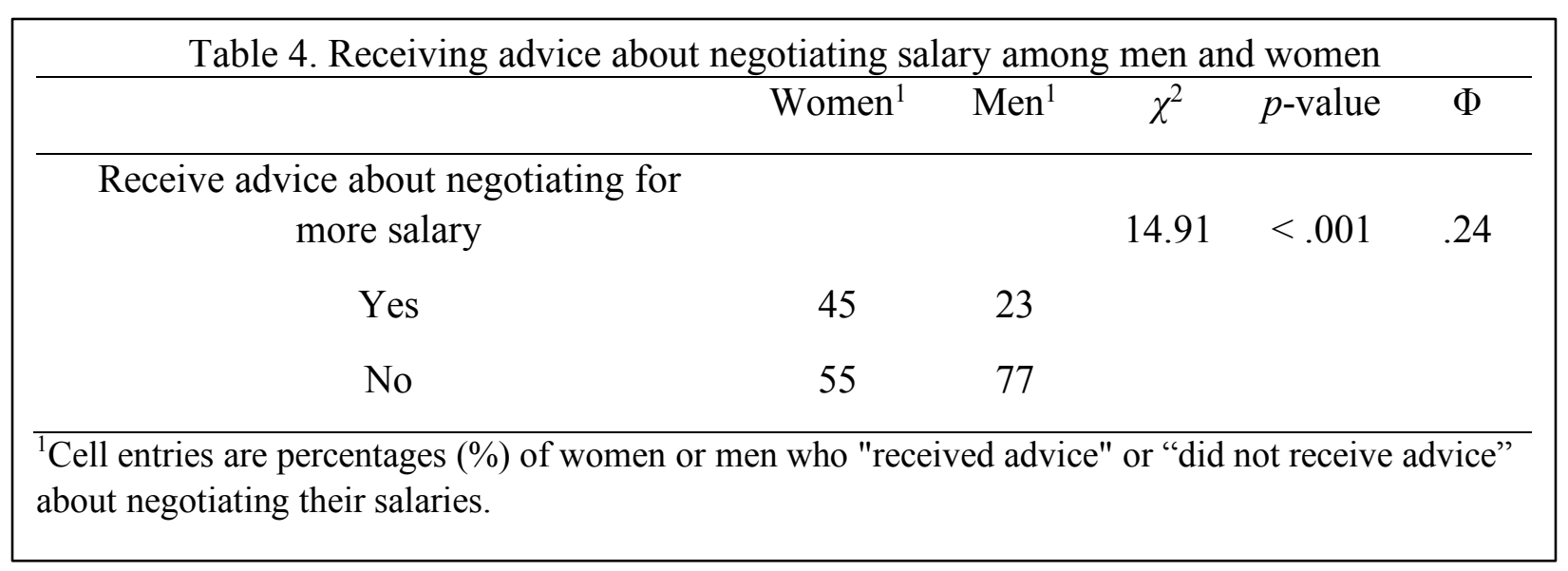

Research Question 2: Do gender differences exist in the outcomes of negotiations?

Women more frequently negotiated a salary increase less than 5\% (61\%) compared to men who were more likely to negotiate a salary increase greater than $5 \%$ above the initial offered salary $(55 \%)$. No significant difference was found between men and women in regard to the percent increase of salary through negotiations $\left(n=73, \chi^{2}=1.93, p=.165\right)$. But, with a relatively small sample size (less than 100), the effect size was between small or minimal and medium or typical $(\Phi=.16)$. This effect size may indicate that gender influences the percent increase in salary through negotiations, with men more likely to receive a greater percent increase from the initial offered salary. Therefore, these findings lend support for hypothesis $2 \mathrm{a}$. 


\begin{tabular}{|c|c|c|c|c|c|}
\hline 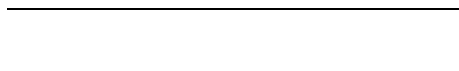 & Women $^{1}$ & $\operatorname{Men}^{1}$ & $\chi^{2}$ & $p$-value & $\Phi$ \\
\hline $\begin{array}{l}\text { Percent increase of salary } \\
\text { through negotiation }\end{array}$ & & & 1.93 & .165 & .16 \\
\hline$<5 \%$ & 61 & 45 & & & \\
\hline$>5 \%$ & 39 & 55 & & & \\
\hline
\end{tabular}

Men who negotiated with men most frequently received an increase in salary greater than $5 \%$ (56\%) compared to women who negotiated with women who less frequently received an increase above $5 \%$ in salary $(29 \%)$ and mixed gendered negotiations fell between these two (man - woman $43 \%$ and woman - man 50\%). These differences were not statistically different $\left(n=73, \chi^{2}=2.85\right.$, $p=.415)$. The effect size was between small or minimal and medium or typical $(V=.20)$ [15], [16]. Therefore, hypothesis $2 \mathrm{~b}$ was rejected as women who negotiated with women were the least likely to negotiate a salary increase greater than $5 \%$.

Table 6. Percent increase of salary through negotiations based on gender of new hire and person negotiating with ${ }^{1}$

\begin{tabular}{|c|c|c|c|c|c|c|}
\hline & Gend & $\begin{array}{l}\text { of Perso } \\
\text { Gende }\end{array}$ & $\begin{array}{l}\text { Negotiat } \\
\text { of new hi }\end{array}$ & g with vs. & & \\
\hline & $\begin{array}{c}\text { Man } \\
- \\
\text { Man }\end{array}$ & $\begin{array}{c}\text { Man } \\
- \\
\text { Woman }\end{array}$ & $\begin{array}{c}\text { Woman } \\
- \\
\text { Woman }\end{array}$ & $\begin{array}{c}\text { Woman } \\
- \\
\text { Man } \\
\end{array}$ & $\chi^{2}$ & $\begin{array}{c}p- \\
\text { value }\end{array}$ \\
\hline $\begin{array}{l}\text { Percent increase in salary through } \\
\text { negotiation }\end{array}$ & & & & & 2.85 & 415 \\
\hline$<5 \%$ & 44 & 57 & 71 & 50 & & \\
\hline$>5 \%$ & 56 & 43 & 29 & 50 & & \\
\hline
\end{tabular}

${ }^{1}$ Cell entries are percentages (\%) of different gender combinations who negotiated " $<5 \%$ " or " $<5 \%$ " above the initial offered salary.

Research Question 3: Can any disciplinary or institutional factors be identified that have an effect on negotiations?

Departments were separated into engineering and non-engineering for the analysis of hypothesis 3a. Non-engineering departments included Biology, Sociology, Psychology, and Philosophy. 
Those who worked in engineering departments more frequently negotiated a salary increase greater than $5 \%$ over the initial offer (57\%) compared to non-engineering departments (33\%). This difference was found to be statistically significant with those working in engineering departments more frequently negotiating a salary increase of greater than $5 \%\left(n=73, \chi^{2}=4.08, p=.043\right)$. The effect size was between small or minimal and medium of typical $(\Phi=.24)$ [15], [16]. Therefore, hypothesis $3 \mathrm{a}$ was accepted with engineering departments more likely than non-engineering departments to receive a greater percent increase in salary through negotiating.

\begin{tabular}{|c|c|c|c|c|c|}
\hline & Engineering ${ }^{1}$ & $\begin{array}{c}\text { Non- } \\
\text { engineering }\end{array}$ & $\chi^{2}$ & $p$-value & $\Phi$ \\
\hline $\begin{array}{l}\text { Percent increase of salary } \\
\text { through negotiation }\end{array}$ & & & 4.08 & .043 & .24 \\
\hline$<5 \%$ & 43 & 67 & & & \\
\hline$>5 \%$ & 57 & 33 & & & \\
\hline
\end{tabular}

Faculty at non- $\mathrm{PhD}$ granting institutions more frequently negotiated a salary increase greater than $5 \%$ compared to $\mathrm{PhD}$ granting institutions (54\% vs. 33\%). This difference was not statistically significant $\left(n=73, \chi^{2}=2.94, p=.087\right)$. The effect size was between small or minimal and medium or typical $(\Phi=.20)$ [15], [16]. Therefore, hypothesis $3 b$ was rejected as non- $\mathrm{PhD}$ granting institutions were more likely to have a greater percent increase in salary through negotiations.

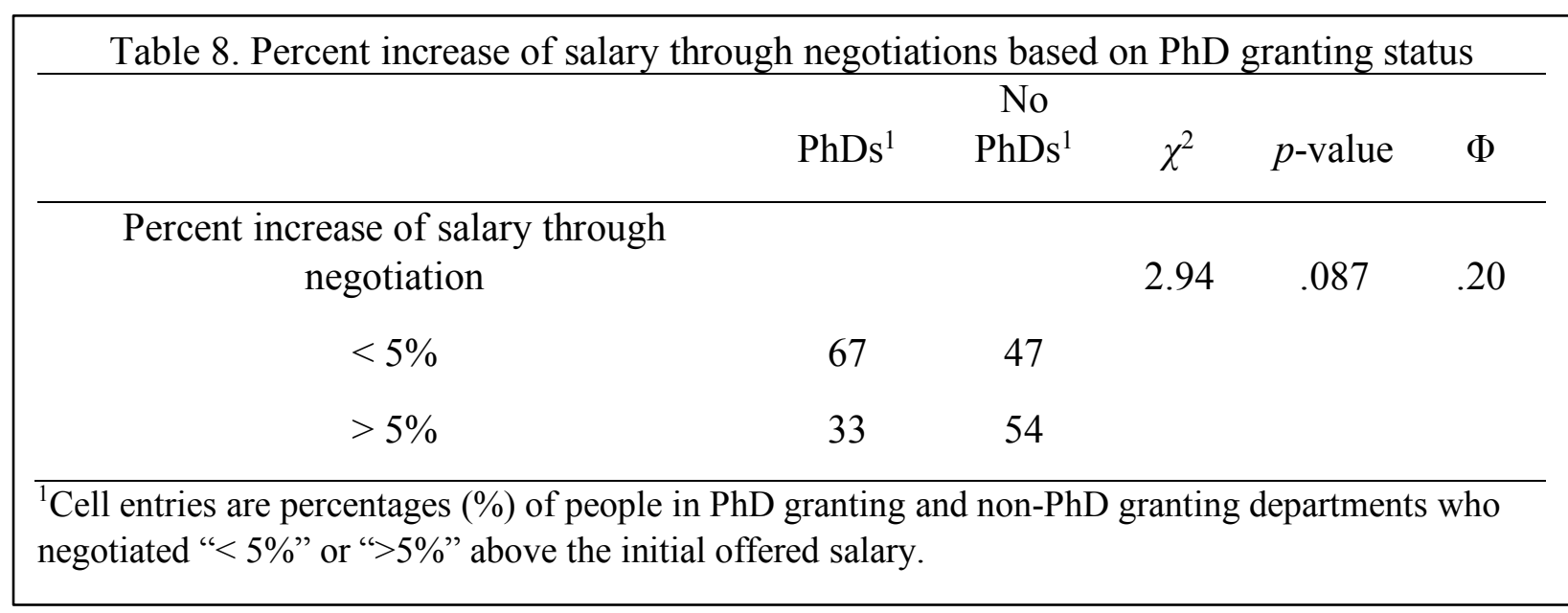

Faculty who negotiated their salaries at institutions that were unionized had greater than a $5 \%$ increase in salary more frequently than non-unionized institutions ( $48 \%$ vs. $44 \%)$. This difference was not statistically significant $\left(n=73, \chi^{2}=.07, p=.792\right)$. Hypothesis $3 \mathrm{c}$ therefore was rejected 
as no statistical difference was found between faculty who negotiate at unionized and nonunionized institutions.

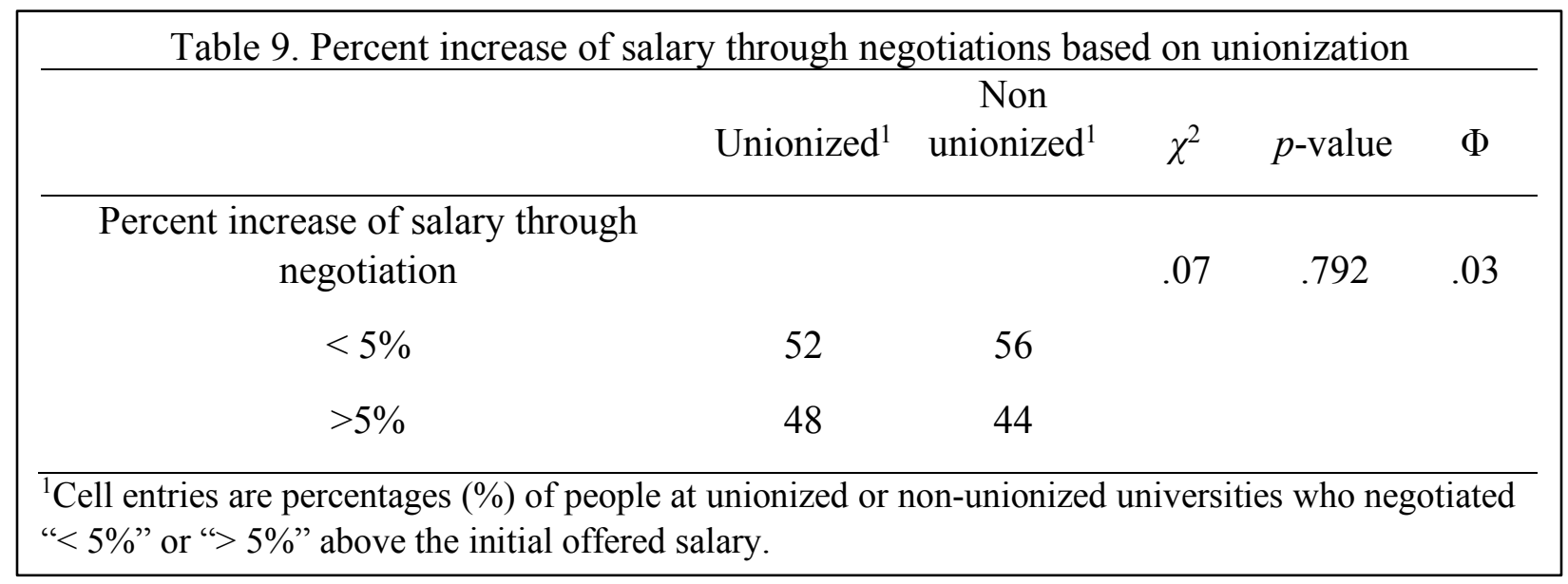

Faculty negotiating at institutions with less than 10,000 students more frequently negotiated greater than a $5 \%$ increase in salary (57\%) compared to institutions with 20,000 students (43\%) and 10,000-20,000 students $(29 \%)$. There was no statistical difference between the three different types of institutions $\left(n=73, \chi^{2}=3.44, p=.179\right)$. The effect size was between small or minimal and medium or typical $(V=.22)$ [15], [16]. Therefore, hypothesis $3 \mathrm{~d}$ was rejected as faculty were more successful negotiating a larger increase in salary at smaller institutions compared to larger institutions.

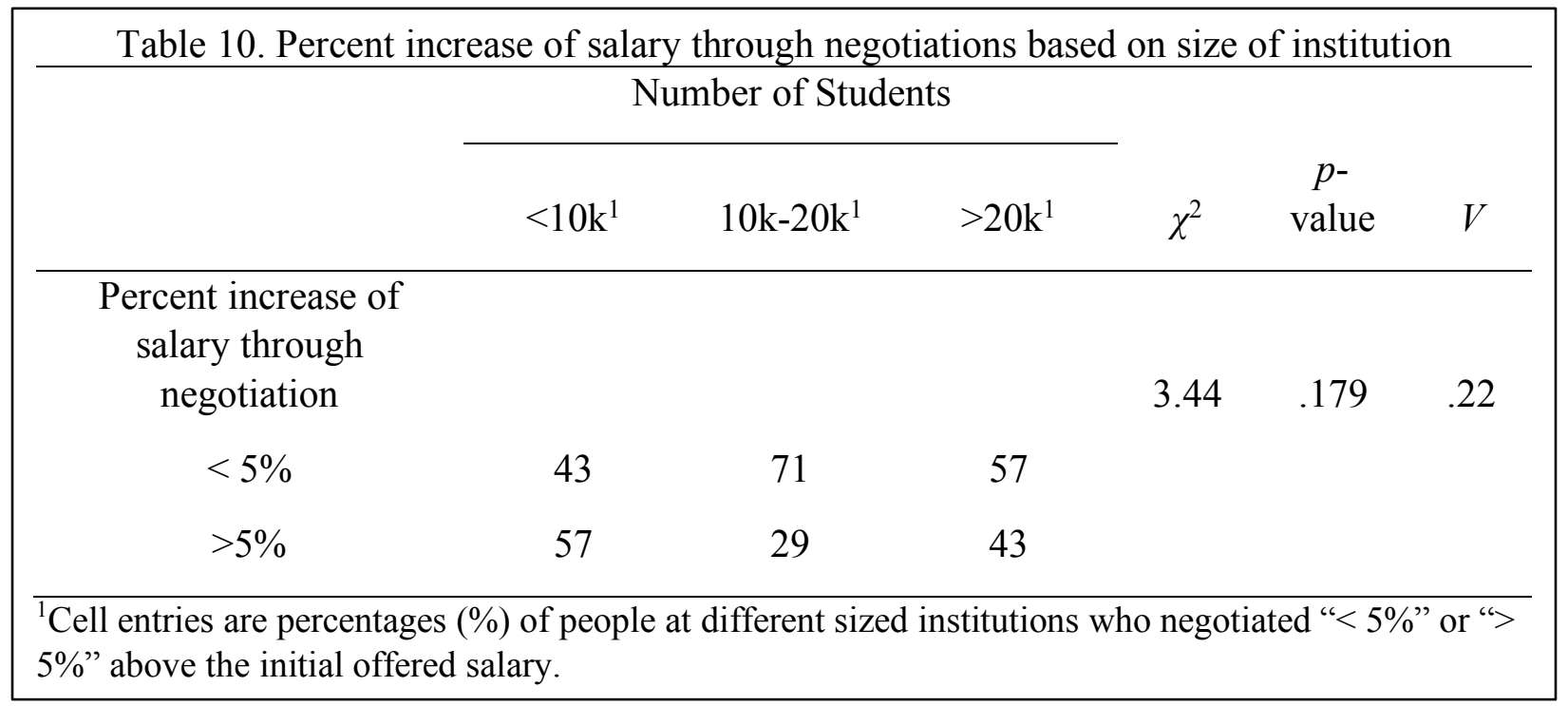

\section{Discussion and Conclusion}

In this survey, women were as likely as men to negotiate their salaries. However, men were more likely to receive a greater increase in salary from negotiating. Additionally, men who negotiated with men were more likely to receive a greater percent increase in salary than women who 
negotiated with women. Faculty members in engineering departments were more likely than those in non-engineering departments to receive a greater percent increase in salary through negotiating. However, other institutional factors, such as size, union status, and degree-granting status, were largely not significant in decisions and outcomes related to negotiations.

These findings add new insights into the persistent wage gap in academia and raise critical questions about the dominant discourse (women don't negotiate) that is used to explain and intervene in the wage gap. Focusing only on negotiation training for women is unlikely to mitigate the wage gap. Research and interventions will need to account for multiple ways in which gender norms and biases affect outcomes, how negotiators are perceived by administrators, administrators' responses to negotiators, how initial salary offers affect the wage gap, interventions for men, and how the men and women administrators may be differentially empowered to give greater compensation to employees, to name just a few issues.

Investigating tenured and tenure-track faculty members' salaries proved to be difficult and often convoluted. While most negotiation research is based upon experimental studies and concrete information provided by a company's human resources department, no such database exists for faculty negotiations. Therefore, we aimed to collect data first-hand from those who were actively engaged in a real negotiation process with professional and financial stakes. Undoubtedly, we learned many lessons throughout the process, including the need to construct a more concise survey instrument, and those lessons will inform our ongoing efforts to study this topic. Furthermore, with the complex nature of gender and negotiation, additional data collection methods should be explored to help us better understand what happens during negotiation processes and how gender factors into those processes.

To that end, we have begun a second phase of the [name removed] project that entails collection of different qualitative data. This phase began with a storytelling circle and methodology discussion held at a conference in January 2018 [17]. Analysis of our survey data is also on-going, with current efforts focused on examining tensions and paradoxes that exist in the data. Findings from the qualitative survey data and storytelling circles will be presented in future articles.

\section{References}

[1] Chronicle of Higher Education. 2017. Gender Pay Gap Persists Across Faculty Ranks. $<$ https://www.chronicle.com/article/Gender-Pay-Gap-Persists-Across/239553>. Accessed April 2, 2018.

[2] P. Umbach, "Gender equity in the academic labor market: An analysis of academic disciplines," Research in Higher Education, vol. 48, no. 2, pp. 169-192, 2007.

[3] K. Sosin, J. Rives, and J. West, "Unions and gender pay equity in academe: A study of US institutions," Feminist Economics, vol. 4, no. 2, pp. 25-45, 1998.

[4] University of Massachusetts Lowell Office of Institutional Research. Factbook 2014-2015. $<$ https://www.uml.edu/docs/Factbook\%202014-15 tcm18-230303.pdf $>$. Accessed April $2,2018$. 
[5] K. Beddoes and A.L. Pawley, "Negotiating an Offer: What Graduate Students and Mentors Can Learn from Others' Experiences," Society of Women Engineers (SWE) Magazine, vol. 59, no.2, pp. 40-44, 2013.

[6] L. Babcock and S. Laschever, Women don't ask. Princeton, NJ: Princeton University Press, 2003.

[7] L. Babcock and S. Laschever, Women don't ask: Negotiation and the gender divide. Princeton, NJ: Princeton University Press, 2009.

[8] K. H. Eriksson and A. Sandberg, "Gender differences in initiation of negotiation: Does the gender of the negotiation counterpart matter?," Negotiation Journal, vol. 28, no. 4, pp. 407-428, 2012.

[9] D. A. Small, M. Gelfand, L. Babcock, and H. Gettman, "Who goes to the bargaining table? The influence of gender and framing on the initiation of negotiation," Journal of personality and social psychology, vol. 93 no. 4, pp. 600-613, 2007.

[10] M. E. Wade, "Women and salary negotiation: The costs of self-advocacy," Psychology of Women Quarterly, vol. 25, no. 1, pp. 65-76, 2001.

[11] L. A. Barron, "Ask and you shall receive? Gender differences in negotiators' beliefs about requests for a higher salary," Human relations, vol. 56 no. 6, pp. 635-662, 2003.

[12] H.R. Bowles, L. Babcock, and L. Lai, "Social incentives for gender differences in the propensity to initiate negotiations: Sometimes it does hurt to ask," Organizational Behavior and human decision Processes, vol. 103 no. 1, pp. 84-103, 2007.

[13] A. H. Eagly and S. J. Karau," Role congruity theory of prejudice toward female leaders," Psychological Review, vol. 109 no. 3, pp. 573-598, 2002.

[14] L. J. Kray and L. Thompson, "Gender stereotypes and negotiation performance: An examination of theory and research," Research in organizational behavior, vol. 26, pp. 103-182, 2004.

[15] J. Cohen, Statistical power analysis for the behavioral sciences ( $2^{\text {nd }}$ ed.). Hillsdale, NJ: Lawrence Erlbaum Associates, 1998.

[16] J. Vaske, Survey research and analysis: Application in parks, recreation and human dimensions. State College, PA: Venture, 2008.

[17] K. Beddoes, C. Llewellyn, and G. Panther. Workshop: Negotiation Experiences and Salary Equity in Higher Education. Hawaii International Conference on Education, Honolulu, HI, January 2018. 